\title{
Fungsi Media dan Partai Politik di dalam Pendidikan Politik untuk Meningkatkan Keterwakilan Perempuan di Legislatif
}

\author{
Siti Hajar \\ Fakultas Ilmu Sosial dan Ilmu Politik, Universitas Jayabaya, Jakarta, Indonesia \\ E-mail: sitihajarsantoso@jayabaya.ac.id
}

\begin{abstract}
Article Info
Article History

Received: 2021-12-27

Revised: 2022-01-22

Published: 2022-02-04

Keywords:

Functions;

Media;

Political Parties;

Education Women's;

Representation.

Abstract

The purpose of this paper is to explain the importance of the function of the media, and political education for the Indonesian people, especially political education for women in various entities. Political education is important to do, because political education can be used as a means of awareness of political and cultural discourse, especially patriarchal culture for the community. The research was conducted in Indonesia. While the method used is a literature review. The unit of analysis used is individuals and groups, namely the organization. This paper explains the importance of political education and the role of the media for all stakeholders, both for political parties, government institutions, and non-government social institutions. The targets and objectives to be achieved are for the community to have a comprehensive understanding in the fields of politics, political ethics and culture, so that they are encouraged to participate in society, including participation in politics. For political parties, political education works to prepare a cadre of future leaders of the nation, so that the life of the nation and state is good. The implementation of political education can be carried out by political parties, universities, the government and other community organizations. The aim is that the public is politically literate, has a good understanding of political culture, especially patriarchal culture which is very influential on women's representation. Women must also understand national, state and community issues. All of the above factors greatly affect women's political representation and participation in the public sphere.
\end{abstract}

\begin{tabular}{l}
\hline Artikel Info \\
\hline Sejarah Artikel \\
Diterima: 2021-12-27 \\
Direvisi: 2022-01-22 \\
Dipublikasi: 2022-02-04
\end{tabular}

Kata kunci:

Fungsi;

Media;

Partai Politik;

Edukasi Wanita;

Perwakilan.

\begin{abstract}
Abstrak
Tujuan dari tulisan ini adalah untuk menjelaskan pentingnya fungsi media, dan pendidikan politik bagi masyarakat Indonesia, terutama pendidikan politik untuk perempuan pada berbagai entitas. Pendidikan politik penting dilakukan, karena pendidikan politik dapat dijadikan sarana penyadaran wacana politik dan budaya, khususnya budaya patriarkhi bagi masyarakat. Penelitian dilakukan di Indonesia. Sedang metode yang digunakan adalah studi telaah pustaka. Satuan analisis yang digunakan individu dan kelompok, yaitu organisasi. Tulisan ini menjelaskan pentingnya pendidikan politik dan peran media bagi semua stake holder, baik bagi partai politik, lembaga pemerintah, dan lembaga kemasyarakatan non pemerintah. Target dan tujuan yang ingin dicapai adalah, agar masyarakat memiliki pemahaman yang komprehensif di bidang politik, etika politik dan budaya politik, sehingga mereka terdorong untuk berpartisipasi aktif dalam masyarakat, termasuk partisipasi di bidang politik. Bagi partai politik, pendidikan politik berfungsi untuk menyiapkan kader calon pemimpin bangsa, sehingga terwujud kehidupan berbangsa dan bernegara yang baik. Penyelenggaraan pendidikan politik dapat dilakukan oleh partai politik, perguruan tinggi, pemerintah serta organisasi masyarakat lainnya. Tujuannya adalah agar masyarakat melek politik, memiliki pemahaman yang baik terhadap budaya politik, khususnya budaya patriarkhi yang sangat berpengaruh terhadap keterwakilan perempuan. Perempuan juga harus memahami permasalahan-permasalahan kebangsaan, kenegaraan, dan kemasyaraakatan. Semua factor di atas sangat berpengaruh terhadap keterwakilan dan partisipasi politik perempuan di ranah publik.
\end{abstract}

\section{PENDAHULUAN}

Kontestasi setiap Pemilu yang kita selenggarakan di Indonesia, seperti Pemilu pada tahun 2014, 2019 dan Pemilu-Pemilu sebelum serta Pemilu sesudahnya kelak, idealnya, dapat kita maknai sebagai proses pemahaman dan proses transformasi pendidikan politik bagi seluruh masyarakat, setiap penyelenggaraan Pemilu, idealnya harus terjadi proses pembelajaran politik bagi warga bangsa, sehingga terjadi proses pemahaman dan penyadaran politik. Pendidikan politik yang dimaksud adalah pendidikan politik 
yang dapat dilaksanakan oleh berbagai pihak seperti partai politik, pemerintah, perguruan tinggi dan lembaga atau institusi kemasyarakatan lainya yang peduli akan pentingnya kehidupan kemasyarakatan yang adil dan demokratis untuk mewujudkan masyarakat yang sejahtera.

Pada hakekatnya pendidikan merupakan salah hak yang paling asasi dan paling mendasar yang dimiliki oleh setiap individu sepanjang hidupnya yang dijamin Undang-Undang (UUD 45), artinya hak untuk mendapatkan pendidikan adalah hak yang melekat dan yang dimiliki oleh setiap individu sebagai warga negara Indonesia selama masa hidupnya, yang dijamin undangundang. Hak untuk mendapatkan pendidikan yang dimaksudkan di sini adalah mencakup hak untuk memperoleh pendidikan formal maupun pendidikan nonformal yang meliputi berbagai level atau tingkatan baik pendidikan yang diselenggarakan oleh pemerintah, perguruan tinggi maupun oleh institusi atau lembaga kemasyarakatan, termasuk hak untuk mendapatkan pendidikan politik. Sebuah negara yang maju adalah negara yang peduli untuk melaksanakan pendidikan bagi warganegaranya, karena hanya bangsa yang mementingkan dan mengedepankan unsur pendidikan bagi warga negaranyalah yang akan menjadi bangsa yang kuat, demikian juga bagi pemerintah Indonesia, pendidikan juga telah dianggap sebagai salah satu faktor yang cukup penting untuk mencapai suatu kemajuan negara, karena jika warganegara Indonesia memiliki tingkat pendidikan yang tinggi, maka berarti sumberdaya manusia yang kita miliki adalah sumberdaya manusia yang memiliki kualitas, terdidik, yang siap bekerja secara professional untuk menghadapi berbagai permasalahan dalam berbagai aspek atau bidang kehidupan, dalam kaitannya dengan bidang politik, pelaksanaan pendidikan politik juga menjadi tanggung jawab pemerintah untuk dilaksanakan, disamping itu partai politik, universitas dan institusi atau lembaga kemasyarakatan lainnya juga dapat berperan aktif untuk menyelenggarakan pendidikan politik bagi warga bangsa.

Secara mendasar Pendidikan politik yang diselenggarakan oleh para pihak idealnya lebih difokuskan pada upaya sebagai untuk untuk memberikan pemahaman kepada masyarakat dan alat penyadaran wacana politik bagi warga bangsa, dengan penyelenggaraan pendidikan politik diharapkan dapat terjadi proses pemahaman wacana politik yang baik bagi publik sebagai warga bangsa, dengan dasar pemahaman politik yang baik, masyarakat akan dapat berpartisipasi dan berperan secara aktif di dalam membangun kehidupan bernegara, berbangsa dan bermasyarakat, sehingga kehidupan yang bermartabat dan berkeadilan dapat diwujudkan di Indonesia, dengan demikian dapat dikatakan, pendidikan politik dapat dijadikan dasar, dan media untuk mendorong partisipasi politik publik warga bangsa di berbagai entitas dan tataran di dalam masyarakat kita. Kemudian dalam kaitannya dengan upaya peningkatan partisipasi politik perempuan, yang salah satunya melalui upaya percepatan pencapaian kuota $30 \%$ perempuan dalam bidang politik pada Pemilu 2009, 2014, 2019, juga diperlukan pendidikan politik.

Seseorang kader yang berpendidikan formal tinggi, ditunjang dengan pendidikan nonformal seperti pendidikan politik yang baik misalnya, akan lebih siap berpartisipasi aktif dalam bidang politik, dalam pendidikan politik akan terjadi proses transfer nilai dan ilmu, sehingga akan terjadi transfer pemahaman atas budaya budaya patriarkhi dan kendala lainnya yang sering mneghambat perempuan masuk ke dunia politik. Pendidikan politik diharapkan dapat menjadi alat atau media pembelajaran politik publik sehingga akan melahirkan partisipasi politik perempuan dan keterwakilan perempuan di dalam kehidupan berbangsa dan bernegara, ddengan demikian dapat dikatakan, penyelenggaraan pendidikan politik dapat dijadikan media untuk meningkatkan keterwakilan dan partisipasi politik perempuan, sekaligus membangkitkan nasionalisme warga bangsa. Pendidikan politik penting terus dilakukan oleh setiap partai politik terhadap perempuan, mengingat hasil beberapa studi menyebut, akibat masih kuatnya pengaruh budaya patriarkhi sehingga perempuan sering dianggap kurang cocok dengan dunia politik karena dunia politik dipersepsikan dan dianggap keras, hal itu masih menjadi kendala yang sangat dominan yang mempengaruhi tingkat keterwakilan perempuan di dalam pengambilan keputusan di ruang publik dan berpengaruh pada partisipasi dan keterlibatan perempuan di bidang politik, oleh karena itu proses penyadaran politik terhadap perempuan harus terus dilakukan oleh berbagai pihak meliputi partai politik, pemerintah, dan institusi atau lembaga kemasyarakatan secara bersama maupun secara terpisah.

\section{METODE PENELITIAN}

Kajian ini menggunakan pendekatan kualitatif dengan metode deskriptif yaitu dengan cara mengumpulkan, menganalisis, membuat gamba- 
ran dan mempersingkat segala kondisi dan situasi dari data yang telah terkumpul. Penelitian ini merupakan penelitian kualitatif reflektif dengan pendekatan studi Pustaka, data-data diambil dari berbagai sumber seperti buku, jurnaldan lainnya, analisis data yang dilakukan untuk menjawab permasalahan yang ada pada penelitian ini adalah reduksi data yang selanjutnya dianalisis berdasarkan teori teori yang dipilih dalam penelitian ini dan disajikan dalam bentuk narasi ilmiah.

\section{HASIL DAN PEMBAHASAN}

Berdasarkan pada masa atau periode waktu, pendidikan politik dapat dikelompokkan menjadi beberapa fase yaitu, fase pertama pada masa kemerdekaan, pendidikan politik mulai dijalankan oleh pemerintah di era revolusi Indonesia (1945-1950), kemudian fase pada masa Demokrasi Liberal (1950-1959) dan fase pada masa Orde Lama (1959-1966), kemudian dilanjutkan fase pada masa Orde Baru (1966-1998) dan selan-jutnya fase pendidikan politik pada masa Orde Reformasi (1998-sekarang). Pendidikan politik yang dilakukan oleh masing-masing Orde pemerintahan, memiliki kekhasan dan keunikan di dalam proses penyelenggaraan yang dilakukan. Pendidikan poltik yang dilaksanakan oleh suatu pemerintahan dan partai politik, dapat berfungsi sebagai pembelajaran politik bagi pemerintahan berikutnya. Oleh karena itu agar suatu pemerintahan efektif, harus memperhatikan pendidikan politik yang telah dilakukan oleh pemerintahan sebelumnya, sehingga program pendidikan politik yang dijalankan efektif, pada fase pertama masa awal kemerdekaan, pendidikan politik lebih ditekankan pada pendidikan politik untuk menumbuhkan sikap patriotisme (patriotic political education), yaitu suatu pendidikan politik yang lebih memfokuskan pada nation and character building. Pendidikan politik yang diselenggarakan lebih menekankan pada aspek bagaimana menjawab tantangan dan permasalahan yang muncul pada masa awal kemerdekaan, membangun karakter dan upaya untuk menumbuhkan rasa nasionalis dan wawasan kebangsaan para pemangku kepentingan, dalam rangka mewujudkan kehidupan berbangsa dan bernegara yang bermartabat dan berkeadilan. Pembangunan karakter dan upaya menumbuhkan nasionalisme dan wawasan kebangsaan pada awal kemerdekaan merupakan hal yang sangat penting dan mendasar, karena hal itu merupakan landasan bagi bangsa
Indonesia untuk membangun, setelah berhasil mengusir penjajah dari bumi Indonesia.

Selanjutnya pada fase masa pemerintahan Soekarno, pendidikan politik lebih ditekankan pada pemahaman dan kesadaran politik, pada masa era Orde Lama (1959-1966), hal itu penting dilakukan, mengingat untuk mengisi kemerdekaan, diperlukan adanya pemahaman dan kesadaran politik yang tinggi untuk mulai membangun Indonesia di dalam berbagai aspek, dengan pemahaman politik yang baik akan Indonesia, maka program pembangunan yang disusun akan sesuai dengan kebutuhan dan aspirasi masyarakat Indonesia, di dalam perjalanannya, proses pendidikan politik yang seharusnya dilakukan untuk meningkatkan pemahaman dan kesadaran politik pada masa itu, ternyata kemudian di dalam pelaksanaannya diselewengkan oleh para pihak yang berwenang. Pendidikan politik pada masa ini kemudian menjadi pendidikan politik yang mengarah pada indoktrinasi, yang dilakukan secara sengaja oleh partai dan pemerintahan yang sedang berkuasa, pengangkatan presiden seumur hidup pada masa itu, menjadi salah satu penanda telah terjadinya penyelewengan pendidikan politik karena hal itu sesungguhnya bertentangan dengan UUD 1945.

Kemudian, pada fase masa pemerintahan Orde Baru (1966-1998), pendidikan politik lebih difokuskan pada upaya penyadaran berpolitik, menumbuhkan wawasan kebangsaan dan pemahaman akan kemajemukan, serta pentingnya masalah integrasi.

Namun kita seperti mengulang kesalahan pada masa pemerintahan sebelumnya, di dalam perjalanannya, pendidikan politik yang dilakukan pada fase ini ternyata kemudian juga diselewengkan oleh pemerintah Orde Baru dari yang seharusnya. Pendidikan politik yang diselenggarakan masa pemerintahan Orde Baru yang seharusnya untuk menumbuhkan kesadaran politik, menumbuhkan wawasan kebangsaan, dan pemahaman kemajemukan dan pentingnya integrasi, kemudian justru diselewengkan untuk pemenangan dan upaya memperkukuh kekuasaan. Proses penyadaran politik, menumbuhkan wawasan kebangsaan dan pemahaman akan kemajemukan masyarakat Indonesia dan pentingnya integrasi yang semestinya dituju di dalam pendidikan politik, justru menjadi kurang mendapat perhatian pemerintah pada masa itu. Salah satu bentuk penyelewengan proses pendidikan politik pada era Orde Baru adalah, digiringnya rakyat ke bilik-bilik suara guna memberikan dukungan penuh terhadap partai 
tertentu, pada setiap penyelenggaraan Pemilu, hal itu berulang setiap lima tahun sekali. Penyelenggaraan Pemilu yang seharusya sebagai proses transformasi pendidikan politik telah diselewengkan pemerintahan pada masa itu. Bahkan kebebasan berpolitik rakyat pada pemerintahan Orde Baru sangat terpasung dan terbelenggu oleh kuatnya kekuasaan pada masa itu. Celakanya jika rakyat tidak memiliki kesadaran politik, maka kepedulian dan rasa tanggung jawabnya terhadap kehidupan berbangsa dan bernegara menjadi amat berkurang. Idealnya, pemerintah dan rakyat harus samasama memiliki kepentingan yang sama, sebab pendidikan politik harus datang dari kedua belah pihak. Pemerintah harus memfasilitasi dan memberikan kemudahan penyelenggaraan pendidikan politik dengan mempertinggi kecerdasan umum masyarakat, sedangkan dari publik, pendidikan politik harus merupakan bentuk tanggung jawab semua partai politik di dalam proses transfer kesadaran berpolitik. Dengan demikian, maka pemahaman kesadaran politik akan tumbuh, dan selanjutnya rakyat akan berpartisipasi aktif membangun Indonesia.

Pada fase selanjutnya, era reformasi (1988 sekarang), kegaduhan kehidupan berpolitik justru berkembang semakin tidak terarah. Nalar elite politik masih menyimpan adanya pengakuan tersirat untuk saling berkuasa, tanpa mempedulikan nasib rakyat. Otoritas pemerintahan kerap diselewengkan demi kepentingan rente ekonomi, cara kerja elite politik seperti inilah yang kemudian cenderung membuat rakyat merasa kepentingannya tidak diperjuangkan, dan pada gilirannya menimbulkan apati dan jarak antara politik dan rakyat. Celakanya, kondisi demikian semakin lama justru semakin melebar menjelang Pemilu 2009, 2014, dan 2019. Pendidikan politik lebih ditujukan untuk saling berkuasa, mengabaikan aspirasi dan kepentingan rakyat banyak, oleh karena itu ke depan perlu perbaikan mendasar arah dan fokus pendidikan politik, agar pemahaman politik rakyat tumbuh. Selanjutnya, arah dan fokus pendidikan politik yang benar akan mampu menjadi media transfer wacana politik publik, pemahaman budaya, yang selanjutnya akan melahirkan partisipasi aktif masyarakat untuk membangun bangsanya.

1. Hak dan Partisipasi Perempuan Dalam Politik

Setiap warga Negara memiliki hak dan kewajiban untuk berpartisipasi di dalam bidang politik, jika rakyat memiliki kesadaran politik mereka akan memiliki tanggung jawab yang besar terhadap kehidupan berbangsa. Demikian pula sebaliknya rasa tanggung jawab politik harus dimiliki oleh rakyat dan pemerintah, keduanya harus memiliki kepentingan yang sama di dalam kehidupan berbangsa dan bernegara, pemerintah dapat berfungsi untuk memudahkan dan memfasilitasi penyelenggaraan pendidikan politik, dengan tujuan mempertinggi kecerdasan umum publik, sedangkan dari publik atau masyarakat pendidikan politik merupakan bentuk tanggung jawab utama partai politik dalam melakukan transfer kesadaran politik. Pada hakekatnya sebagai warga negara, perempuan sebagaimana laki-laki memiliki hak yang sama atas partisipasinya di berbagai bidang, termasuk partisipasi atau keterlibatannya dibidang politik, sebagaimana diamanatkan oleh Undang-Undang Dasar kita, disamping itu pemerintah Indonesia juga telah meratifikasi konvensi CEDAW (Convention on the of All Forms of Discrimination Againts Women) atau Konvensi International tentang penghapusan segala bentuk kekerasan terhadap perempuan, yang tertuang dalam UU no.7 tahun 1984, khususnya pasal 7 yang memuat tentang hak perempuan untuk dipilih dalam sebuah pemilihan umum dan hak perempuan untuk turut merumuskan dan menjadi pejabat negara.

Berdasar Undang-undang di atas, keterlibatan perempuan dalam bidang politik sebenarnya adalah suatu keniscayaan, namun dalam kenyataannya, perempuan masih mengalami banyak kendala untuk berpartisipasi dalam bidang politik. Sebagaimana telah disebut di atas masih kentalnya budaya patriarkhi yang berkembang di dalam masyarakat Indonesia, ternyata menjadi kendala yang dominan atas keterlibatan perempuan di dalam bidang politik di Indonesia, budaya patriarkhi telah mengajarkan bahwa dunia politik adalah dunia yang keras, oleh karenanya dunia tersebut tidak pantas dan tidak cocok dimasuki oleh perempuan. Pendomestifikasian terhadap peran perempuan berdasar atas stereotipi gender, yang mengajarkan bahwa pekerjaan domestiklah yang cocok dan pantas sebagai pekerjaan perempuan di dalam rumahtangga, adalah suatu realita yang masih dapat dengan mudah kita lihat di dalam kehidupan masyarakat Indonesia. Bahkan, sosialisasi nilai-nilai patriarkhi tersebut di dalam keluarga masih berlangsung secara sistematis sampai sekarang, itulah tantangan 
yang mesti harus kita hadapi, yang ternyata merupakan kendala yang paling dominan yang mempengaruhi tingkat keterlibatan perempuan dalam bidang politik dan pengambilan keputusan yang masih rendah, untuk mengatasi kendala budaya tersebut diperlukan upaya yang intensif yang dilakukan secara terus-menerus oleh berbagai pihak, sehingga keterlibatan perempuan dalam bidang politik dapat ditingkatkan. Di samping itu, diperlukan juga upaya untuk mengatasi kendala bidang lain seperti kendala psikhologis, adanya anggapan bahwa terjun di dalam dunia politik dan dalam pengambilan keputusan adalah bukan tindakan yang melawan kodratnya sebagai perempuan. Kemudian kendala lain yang harus diatasi oleh perempuan adalah kendala sosial ekonomis, dalam hal ini perempuan juga dituntut untuk memiliki kemandirian secara ekonomis dan secara sosial, dengan kata lain perempuan harus bisa mengatasi ketergantungan mereka terhadap laki-laki.

Setelah kendala budaya, kendala psikologis dan kendala sosial ekonomis dapat dicarikan solusinya, perempuan masih membutuhkan ketersedian sistem pemilu yang ramah terhadap perempuan guna meningkatkan keterlibatan perempuan dbidang politik dan pengambilan keputusan, realitas menunjukkan, bahwa perempuan memiliki kebutuhankebutuhan khusus yang hanya dapat dipahami secara baik oleh perempuan itu sendiri. Kebutuhan-kebutuhan tersebut meliputi:

a) Isu tentang kesehatan reproduksi, sepeti cara berkeluarga berencana (KB) yang aman.

b) Isu tentang kesejahteraan keluarga, termasuk harga sembilan bahan pokok yang terjangkau, masalah pendidikan dan kesehatan keluarga.

c) Isu kepedulian terhadap anak, kelompok usia lanjut dan tuna daksa.

d) Isu tentang kekerasan seksual dan kekerasan dalam rumah tangga.

Oleh karena itu untuk mengatasinya, diperlukan keterlibatan perempuan di dalam pengambilan keputusan, baik dilegislatif, eksekutif dan diyudikatif, yang sampai sekarang masih sangat rendah sekitar 12\% jika dibandingkan dengan jumlah penduduk yang lebih dari 50\% dari penduduk Indonesia. Selanjutnya untuk meningkatkan partisipasi politik perempuan perlu mewujudkan keterwakilan perempuan $30 \%$ seperti yang di- amanatkan di dalam kuota pada pemilu 2014, perlu disusun langkah-langkah antara lain:

a) Undang-undang Pemilu harus dipahami, dan disosialisasikan kepada perempuan sampai level daerah.

b) Perempuan harus memahami proses dan sistem pencalonan masing-masing partai.

c) Perempuan harus memahami pemetaan dan perolehan suara pemilu 2009, dan suara setiap pemilu.

d) Perempuan harus mengetahui skala prioritas daerah basis.

e) Perempuan harus melakukan lobi dengan pimpinan partai di tingkat pusat maupun daerah.

f) perlunya mensosialisasikan UndangUndang Pemilu kepada masyarakat, khususnya mengenai peluang keterlibatan perempuan di legislatif yang telah disahkan.

\section{Deviasi Fungsi Partai Politik}

Dalam praktiknya dimasyarakat fungsi Partai politik di dalam proses pendidikan politik sering diselewengkan atau sering terjadi deviasi, partai politik hanya dijadikan alat legitimasi meraih kekuasaan lewat program politik. Rakyat cenderung dijadikan boneka politik sekaligus sebagai korban kebijakan politik, deviasi fungsi politik dan partai politik inilah yang menjadi awal munculnya berbagai masalah dalam kehidupan politik, bahkan yang sering terjadi prioritasnya hanya kepentingan politik, jika hal itu terjadi maka dapat dikatakan bahwa dalam khasanah politik tidak ada etika politik, objektivitas, apalagi rasionalitas, karena yang ada hanya kepentingan. Pendidikan politik hanya diberikan sebatas pada kajian fakta, bukan pada tataran kajian konsep dasar, idealnya setelah kajian fakta, pada proses pembelajaran pendidikan politik harus dilanjutkan pada tingkat implementasi politik pada sektor dimana kekuasaan dapat dimengerti dan dipahami dengan baik oleh rakyat secara rasional.

Jika hal sebaliknya yang terjadi maka telah terjadi disfungsi pendidikan politik, materi substansial kerap direduksi sehingga konsep pendidikan politik menjadi dangkal dan monoton, dampaknya ketika publik berhadapan dengan permasalahan politik praktis, yang terjadi ialah menjamurnya apati publik tanpa mengerti apa yang seharusnya dilakukan. Fakta ini membuktikan bahwa pendidi- 
kan politik di Indonesia sampai Pemilu 2014, dan pemilu 2019 belum menunjukkan hasil yang menggembirakan. Oleh karena itu diperlukan perubahan yang mendasar dan perubahan arah pendidikan politik sebagaimana mestinya, yang berfungsi untuk menumbuhkan pemahaman dan kesadaran politik, pemahaman akan kemajemukan dan pentingnya integrasi bangsa, sehingga rakyat berpartisipasi aktif di dalam proses pembangunan berbangsa dan bernegara, untuk mengatasi hal itu idealnya partai politik harus mulai membuat program pendidikan politik yang substansial untuk semua level kadernya, sehingga pemahaman politik yang terdistorsi dapat direduksi dari peta kognitif rakyat Indonesia. Sebab fungsi utama partai politik adalah sebagai penyalur pendidikan politik guna membangun etika dan budaya politik yang sesuai dengan Pancasila dan UUD 1945. Jika hal itu dilakukan maka apati publik yang sekarang cenderung meningkat, secara perlahan diharapkan dapat diatasi, karena pada hakekatnya pendidikan politik harus mampu menghadirkan proses dan transfer politik, dengan demikian pendidikan politik dapat berfungsi sebagai alat penyadaran wacana politik masyarakat. Selanjutnya, pendidikan politik yang semacam itu, diharapkan akan menumbuhkan pemahaman atas konsep dan fakta, nasionalisme dan wawasan kebangsaan, sehingga mendorong partisipasi politik masyarakat yang semakin meningkat.

\section{SIMPULAN DAN SARAN}

\section{A. Simpulan}

Berdasarkan uraian di atas maka dapat disimpulkan hal-hal sebagai berikut:

1. Partai politik memiliki beberapa fungsi yang harus dijalankan, antara lain fungsi partai politik sebagai sarana pendidikan politik, fungsi sebagai sarana stabilitas politik, fungsi sebagai sarana partisipasi politik, fungsi seleksi kepemimpinan dan fungsi sebagai penyalur aspirasi rakyat..

2. Untuk memberikan pembelajaran dan pemahaman politik kepada masyarakat, khususnya kepada perempuan, partai politik harus melaksanakan dengan sungguh-sungguh fungsi pembelajaran politik guna membangun etika dan budaya politik yang sesuai dengan nilai-nilai Pancasila dan UUD 1945 dan meningkatnya keterwakilan perempuan;
Munculnya pemahaman politik masyarakat melalui pendidikan politik dan pembelajaran politik, dan meningkatnya keterwakilan dan partisipasi politik perempuan, diharapkan akan tercipta kehidupan berbangsa, bernegara dan bermasyarakat yang bermartabat dan berkeadilan.

\section{B. Saran}

Pembahasan terkait fungsi media dan partai politik di dalam pendidikan politik untuk meningkatkan keterwakilan perempuan di legislatif dalam penelitian ini masih sangat terbatas dan membutuhkan banyak masukan dan saran untuk penulis selanjutnya adalah mengkaji lebih dalam dan secara komprehensif

\section{DAFTAR RUJUKAN}

Abdullah, Irwan. Seks, Jender dan Reproduksi Kekuasaan. Yogyakarta:

Andriana, Nina, et.al. Perempuan, Partai Politik, dan Parlemen: Studi Kinerja Anggota Legislatif Perempuan di Tingkat Lokal. Jakarta: LII-Konrad Adenaur Stiftung. 2012

Anis, Qosim Ja'far, Muhammad. Perempuan dan Kekuasaan, Menelusuri Hak

Arianto, Bambang. "Disfungsi Pendidikan Politik" dalam Media Indonesia, 22

Crompton, Rosemary and Michael mann, (ed.). Gender and Stratification.

Djapar Dwi Septiawati. 2020. "Perempuan dan Pencegahan Korupsi" dalam Media Indonesia, 11-12-2020. Jakarta: Media Group

Freyer, Barbara Stowasser. Reinterpretasi Gender, Wanita dalam Al-Qur'an,

Hadits, dan Tafsir (terjemahan). Bandung: Pustaka Hidayah, 2001

Hartiningsih, Maria \& Ninuk M Pambudy. "Bertimbang Slogan Perempuan Pilih

Koran Tempo, Jakarta: 26-Maret-2013

Maxim, Sardi (ed). Perempuan di Parlemen, Bukan Sekedar Jumlah (Seri Buku

Membangun Good Governance. Jakarta: el.Kahfi, 2002 
Nasir, Sudirman H. "Jalan terjal perempuan di panggung politik." dalam Kompas,

Perdana, Aditya. "Wajah aktivis Perempuan Dalam Parlemen: Prestasi dan Rekomendasi Politik". dalam Jurnal Perempuan 81, Mei 2014.

Phillips, Anne. The Politics of Presence: The Political Representation of Gender, Ethnicity, and Race. Oxford: Oxford University Press. 1995

Politik dan Persoalan Gender dalam Islam. Bandung: Penerbit Zaman, 1998
Subhan, Zaitunah. Peningkatan Kesetaraan dan Keadilan Jender dalam

Subono, Nur Iman. "Partisipasi Politik Perempuan, Politik Elektoral dan Kuota Kuantitas, Kualitas dan Kesetaraan?" dalam Jurnal Perempuan 79, November 2013 im Peneliti CSIS. Penyempurnaan Sistem Pemilu Proporsional Terbuka. Tidak dipublikasi. 2007.

UN WOMEN. Women's Right to Equality: The Promise of CEDAW. 2016

Wijaksana, MB. Modul Perempuan untuk Politik. Yayasan Jurnal Perempuan \& AusAID. 2004 